İş ve İnsan Dergisi I The Journal of Human and Work

Y1l | Year: Nisan | April 2016

Cilt-Say1 | Volume-Issue:3(1)

ss I pp: $53-63$

doi: 10.18394/iid.28545

e-ISSN 2148-967X

http://dergipark.ulakbim.gov.tr/iid/

Research Paper

\title{
Employee Relations Strategy: Implication for Performance in Lagos State University, South-West, Nigeria
}

\author{
Çalışan İlişkileri Stratejisi: Lagos Devlet Üniversitesi, Güney-Batı, Nijerya'da \\ Performans Çıkarımı
}

Rowland
Worlu*

Adewale

Osibanjo
Odunayo Paul
Salau

Ogunnaike
Ebeguki
Igbinoba

Department of Business Management, Covenant University, Ota, Nigeria

\section{ARTICLE INFO}

\section{Keywords:}

Organizational policies, Promotion, Equity

Recognition, Mentoring, Retention,Performance.

\section{Article history:}

Received 11 November 2015

Received in revised form -

Accepted 15 December 2015

\begin{abstract}
The incessant industrial action, strike, boycotting among workers in the educational sector especially in the public universities is becoming a worrisome phenomenon. This paper examined the impact of employee relations strategy (Organizational policies, Promotion, Equity, Recognition and Mentoring) on job performance in Lagos State University, Southwest, Nigeria. A model was developed and tested using One hundred and thirty six (136) copies of valid questionnaire, which were completed by staff in the State owned university, Lagos, Nigeria. Structural Equation Modeling was adopted to test the hypotheses and relationships that might exist among variables. Results of the analysis indicates that equity, promotion, mentoring and recognition have positive influence on employees' performance. While in the opposite direction, organizational policies have negative and insignificant effect on job performance which suggest that increase in employees' performance will require that managers pay more attention to friendly organizational policies.
\end{abstract}

ÖZ

Özellikle devlet üniversitelerinde gerçekleşen kesintisiz işçi hareketleri, grevler ve çalışanlar arası boykotlar; eğitim sektörü için kaygl verici bir olgu haline gelmiştir. Bu çalışmanın temel amacı, Lagos Devlet Üniversitesi, Güney-Batı, Nijerya'da, çalışan ilişkileri stratejilerinin (örgütsel politikalar, terfi, adalet, takdir ve mentorluk) performans üzerine etkilerini incelemektir. Geliştirilen model, Lagos, Nijerya'daki devlet üniversitesinin çallşanlart tarafindan doldurulmuş yüz otuz altı (136) geçerli anket kullanılarak test edilmiştir. Değişkenler arasında bulunması muhtemel ilişkilerin ve hipotezlerin test edilmesi için Yapısal Eşitlik Modeli kullanılmıştır. Analiz sonuçları adalet, terfi, mentorluk ve takdirin çalışanların performansı üzerinde olumlu etkisi olduğunu göstermektedir. Aksine, örgütsel politikaların çalışanların performansı üzerinde olumsuz ve önemsiz etkisi olduğu görülmüş̧ür. Elde edilen sonuçlara göre, çalışanların performansındaki artış, yöneticilerin daha uygun örgütsel politikalara önem vermesini gerektirmektedir.

*Correspondent Author: Odunayo Paul Salau, Lecturer, Covenant University, College of Business and Social Sciences, odunayo.salau@covenantuniversity.edu.ng 


\section{INTRODUCTION}

Management of people at work is an integral part ofmanagement process in providing enabling work environment and retaining employees. Employees are one of the most important determinants and leading factors that facilitate the success and failure of any organization in a competitive environment. The survival and prosperity of a company in the turbulent and highly competitive environment of today depends mainly on the quality of its employees. This quality itself is a reflection of the breadth and depth of the managers' knowledge of the functions to be performed in engaging competent employees and promoting flexible organizational policies. A growing number of organizations see human resources as major contributors to accomplishing corporate objectives. While others now recognize the fact that employing effective employee relation strategies can be the greatest strength of their organizations. Ever since the conception of modern economic organizations, employee relation has been the most critical element in both public and private sectors (Albrecht, 2010). The growing competitions in Nigeria especially in the tertiary institutions have called for consistent implementation of effective strategies to enhance harmonious relationship between employers and employees, thereby reducing workplace conflict. Many studies (Cooper \& Payne, 2008; Aluko, 2007; Crandall \& Perrewe, 2005; Allen, Eby, Poteet, Lentz, \& Lima, 2004) have indicated that workplace conflict is a significant factor that may affect job performance. Hameed (2009) posits that managing the relationship between an employer and employee is a contentious issue that may affect the performance of both management and staff in Nigerian tertiary institutions. It is also argued that this relationship can influence employees' attitudes (Falola, Ibidunni \& Olokundun, 2014; Redmond, 2013), commitment and involvement (Wagner \& Harter, 2006) which eventuallycan result to retention (Taiwo, 2010; Stajkovic \& Fred, 2003) or turnover (Robbins \& Judge, 2008), displeasure, tiredness, dissatisfaction and low productivity (Kaufman, Chapman \& Allen, 2013).

The incessant industrial action such as strike, boycotting among workers especially in the public universities, is becoming a worrisome phenomenon in the educational sector. The causes of these industrial action can be attributed to many factors associated with employment relations. Studies have indicated specific issues that can adversely affect employee relations and ultimately lead to workplace conflict within the public university system. One of the imperative factors is inequitable pay which has an adverse effect on job performance (Adeniji \& Osibanjo, 2012). Inequitable pay is an indispensable factor that occurs as a result of cost reduction (Aluko, 2007). Rigid bureaucratic structure and organizational climate (Spector, 2008) and uncertainty (Pinder, 2008) also affect employees' satisfaction negatively. Carter and Aston (2002) revealed that coercion and poor team building affects corporate performance. Other mitigating sources include lack of participation/involvement in decision making (Nolan, 2012); longer working hours (Aluko, 2007), inadequate capacity development (Gennard \& Judge, 2002), insufficient welfare services (Cooper \& Payne, 2008); poor relationship with supervisors and colleagues (Oakland \& Oakland, 2001); increased industrial hazard (Siegel, Schraeder \& Morrison, 2007; Harlow \& Lawler, 2000); job insecurity (Manjunath \& Rajesh, 2012) and delay in payment of salary. The fulfillment of the above factors ultimately leads to employees' retention and increased involvement. Numerous studies (Albrecht, 2010; Hameed, 2009; Crandall \& Perrewe, 2005) proposed that increased level of employment relationship leads to higher job satisfaction. Other studies (Manjunath \& Rajesh, 2012; Albrecht, 2010; Pinder, 2008; Oakland \& Oakland, 2001) indicated that when employees are satisfied with their jobs, they tend to be more committed and productive in their organization. The level of employees' retention and involvement is a function of employees' relation strategies experienced by the workers especially in the tertiary institutions. Thus employer relations strategy in State universities is an unexamined genre in scholarly literature. It is this dimension that is of preponderant concern in this paper which is, to examine the effects of employee relations strategy (organizational policies, recognition, promotion, equity \& mentoring) on job performance in a State owned university.

\subsection{Statement of the Research Problem}

University's continued existence and sustainability in competitive environment requires the provision of an environment that stimulates labour 
management relations. It is essential to note that when employment relationship is defective, there are tendencies for many factors to emerge which will adversely affects job performance. However, university management must have the capability not only to enhance peaceful co-existence, but must also intensify efforts to prevent work related conflict occurring at workplace via consistent promotional opportunities, appropriate communication style, healthy ethical attitude, change management, propermanagerial style and other motivational factors (Taiwo, 2010; Wagner \& Harter, 2006).

Employee relations strategy comes in many forms depending on the nature and size of the organization. Employee relations strategy has been found to be an important aspect for effective and efficient management of organizations, yet there is little evidence for the implementation of such strategy in the Nigerian University system especially the State owned universities. Employeerelations strategy as an independent variable can be influenced by other variables such as organizational policies, recognition, promotion, equity \& mentoring and so on.The significance of employee relations in maintaining peace is well known, but this becomes challenging where inequality and poor implementation is on the high side.Over the years, it has been observed that poor implementation of collective agreements reached by the parties/actors and increase in pay inequality has led to the development of distrust, apprehension and emotional exhaustion which are quite obvious in the public universities.

In the Nigerian university system, employee relations strategy and performance are linked with wages/salaries, workplace climate and other benefits, whereas other factors such as organizational policies, recognition, promotion, equity and mentoringare not being addressed.

Studies (Majunath \& Rahesh, 2012; Mike, 2008; Wagner \& Harter, 2006) have also revealed that peaceful co-existence between the parties (government/employers and employees) largely contributes to employees' satisfaction, but these studies failed to identify the strength and degree of the relationship between employee relations and work performance.

However, previous studies (Albrecht, 2010; Cooper \& Payne, 2008; Mike, 2008; Hicks \& Caroline, 2007) reveals that employee relations is no longer a new practice of human resource management and organizational behavior but in spite of the attention and resources paid to the practice, public (State) universities are still prone to incessant industrial action. Though few studies have been conducted in the Western world using other sectors, but limited or no empirical studies have been conducted using tertiary institutions especially State owned universities in South-West, Nigeria. Therefore, this study attempts to examine whether the results achieved in the western world can be replicated with a wider scope in Nigeria. Hence, the relationships between independent variables (such as organizational policies, recognition, promotion, equity, mentoring) and dependent variable (performance) were discussed and this necessitated the need for specific research questions for the study as follows:

1. To what extent has organizational policies $(\mathrm{H} 1)$ and recognition $(\mathrm{H} 2)$ been impactful on employee retention (direct) and performance (indirect)?

2. In what ways has equity (H3) affects employees' retention (direct) and performance (indirect)?

3. To what extent has promotion (H4) and mentoring (H5) influence employee satisfaction

Figure 1: Conceptual Framework

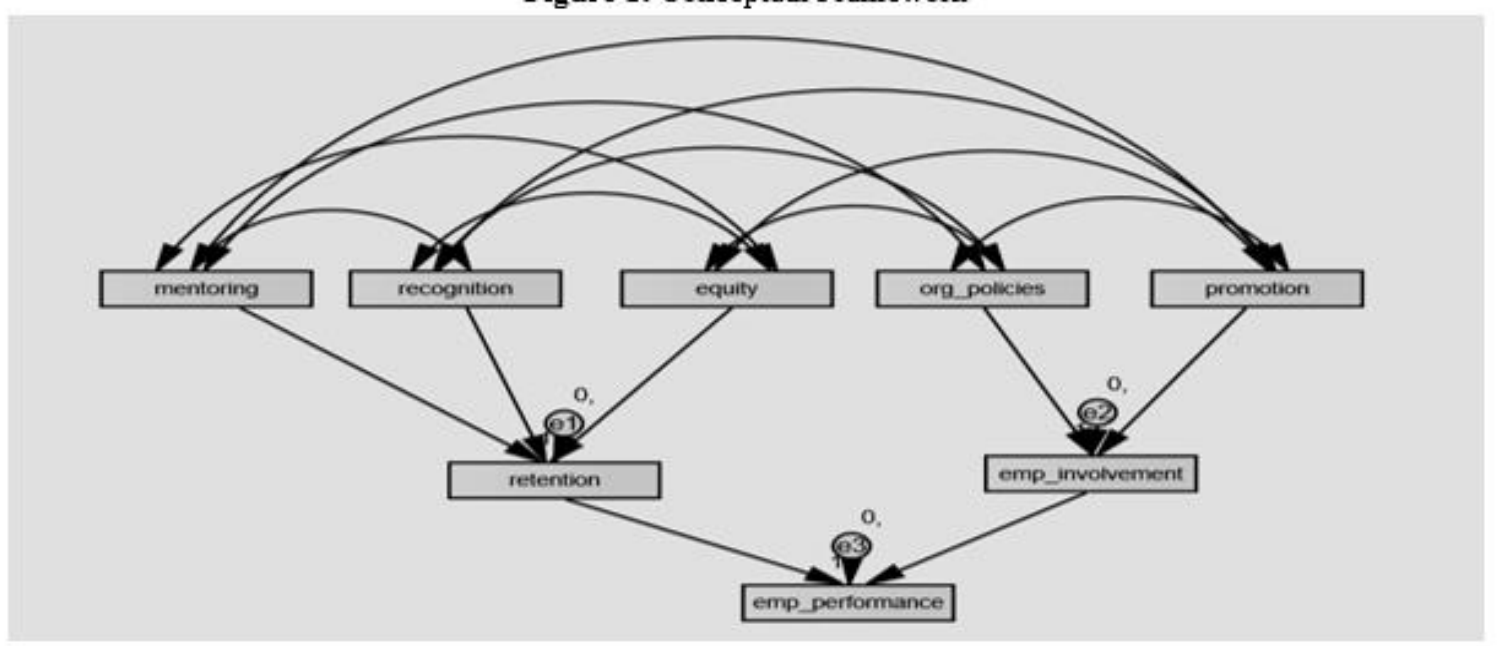


(direct)?

Research questions are depicted in Figure 1 (Conceptual Framework).

\section{LITERATURE REVIEW}

\subsection{Employee Relations}

Employee relation has become a vital ingredient for enhancing performance and the productivity of an organization. The management and co-ordination of human activities have become the cornerstone for achieving organizational survival. This achievement facilitatesthe protection of employees' interest and their welfare for the purpose of avoiding conflictual relations between the employer and the employee (Mike, 2008). Employee relations focuses on the management of the relationship between the employees and the employers in order to heighten their commitment (Gennard \& Judge, 2002), passion, performance (Hameed, 2009), loyalty, productivity (Mike, 2008) and motivation (Crandall \& Perrewe, 2005). Employee relation largely focuses on the prevention of conflictual issues and solving problems in the workplace (Cooper \& Payne, 2008). Some problems arise in the workplace especially when supervisors correct performancesthat are below expected results. This is why Human Resource managers should provide disciplinary approaches that are progressive and also ensure that humane procedures are followed while settling disputes and resolving grievances of employees (Harlow \& Lawler, 2000). Good employee relations also ensures that employees are given necessary guidance and information which can help to promote the practices, programmes, philosophies and policies of the organization (Redmond, 2013; Dessler, 2004). It also ensures that the employees have information about their rights and are helped to resolve their poor performance issues or workplace misconduct. Employee relations strategy arises in a wide range work situations but become worse when employees perceived that they are underpaid or have little or no control over work processes. Poor employee relation strategies adopted by employers of labourcan be caused by numerous factors such as lack of recognition, lack of workers participation in decision making, rigid bureaucratic structure (Leblebici, 2012), poor organizational climate (Pinder, 2008), poor management style (Nelson, 2005), non-supportive environment (Al-Anzi, 2009), pay inequality (Redmond, 2013; Stecher \& Rosse, 2007), inadequate mentoring programmes (Dessler, 2004), amongst other factors.

\subsubsection{Organizational Policies, Employee Retention and Performance}

Organizations formulate and implement effective HR policies that accurately reflect their core values and philosophies; and the relationships between management (employer) and employees; sometimes the policies are established to solve current and future contingencies. The more flexible and consistent these policies are, the greater the level of employees' involvement (Osibanjo, Salau \& Falola, 2014). The organizational policies mostly cover areas like: promotional system, change management, compensation packages (Pinder, 2008), recruitment strategies, occupational health and safety, labour-management relations, information and communication system (Oakland \& Oakland, 2001).The study therefore hypothesized that:

Hypothesis 1: Organizational policies have positive effect on employees' retention and performance.

\subsubsection{Recognition, Employee retention and Performance}

Recognition has become a strategic method of facilitatingemployee retention in the recent days (Kaufman, et al., 2013). Some studies (Leblebici, 2012; Mike, 2008; Huges, 2007) added that recognition has contributed to mutual relationship and cohesiveness between employers and employees and this thereby help in reducing their intention to leave or absent from work (Nelson \& Quick, 2005; Rothwell \& Kazanas, 2004; Banjoko, 2002). Al-Anzi (2009) pointed that lack of recognition, career development and career opportunities are major reasons for employees' intention to leave an organization for another. A Study by Greenberg and Baron (2003) also indicated that recognition in terms of workers participation in management, respect, self fulfilment are important factors that help in influencing the satisfaction and retention level of an employee. Based on the above, the study therefore hypothesized that:

Hypothesis 2: Recognition has positive influence on retention and performance.

\subsubsection{Equity, Employee retention and Performance}

Equity is of great importance to most organizations. An essential strategy for talent retention is the establishment and sustenance of an equitable work environment (Redmond, 2013; Siegel, et al., 2007; Adams, 1963). Equity is fundamental to employment relationship because it is necessary for 
employees to perceive a sense of fairness in terms of compensation, support, appreciation, recognition, support, growth and advancement for the work they are doing (Stecher \& Rosse, 2007). Inequity raises dissatisfaction, displeasure and disillusionment (Albrecht, 2010; Hicks \& Caroline, 2007). Dissatisfaction and disillusionmentpromotes work related stress which eventually can lead to low involvement and commitment. When workers sense that management are treating them unfairly, they turn out to be less committed and sometimes counter-productiveand if this is not controlled, it can lead to low capacity development, low commitment, absenteeism, and high attrition rate (Aluko, 2007), therefore we hypothesized that:

Hypothesis 3: Equity has positive influence on retention and performance.

\subsubsection{Promotion, Job Satisfaction and Performance}

Promotion is an indispensable and strategic tool for enhancing job satisfaction and increased performance. Numerous studies like (Chan \& Mak, 2012; Demet, 2012; Dessler, 2004) pointed that employees feel motivated when they perceive consistent promotional opportunities. Redmond (2013) argued that some factors such as advancement, promotion, learning and career development, appreciation and enabling environment give employees greater opportunities which significantly influence their attitude to work. However, when promotions are not delayed unduly and free from mediocrity (Finegold \& Frenkel, 2006), employees tend to make outstanding results possible in the organization (Salau, Falola \& Akibonde, 2014; Albrecht, 2010; Banjoko, 2002). To buttress this fact, Al-Anzi (2009) adduced that absence of promotional system and opportunities may lead to absenteeism, high turnover rate, low commitment and performance which make the realization of organizational objectives invisible. In order to ascertain the relationship between ergonomics and employee satisfaction, we hypothesized that:

Hypothesis 4: Promotion has positive effect on employee satisfaction and performance.

\subsubsection{Mentoring, Employees' Involvement and Job Performance}

Mentoring has become a predominant factor of career and professional development in both the public and private sector.Mentoring is typically a formal or informal affiliationthat involves effective communication between two persons (Bozeman \& Feeney, 2007). One may be senior mentor (usually outside the protégé's chain of supervision) and the other a junior protégé. Mentorship is an interpersonal (Parsloe, 2000) and developmental relationship (Pompper \& Adams, 2006; Allen, vd., 2004) in which a more wellinformed, knowledgeable, educated and experienced individual assist in building, guiding and directing the efforts of a less skilledand knowledgeable individual. The mentor may be an adult or young person, but have a special area of proficiency and expertise. It is a capacity development relationship between someone with immenseknowledge and a learner (Allen, Eby \& Lentz, 2006). Mentoring is a systematic process for transferring formal and informal knowledge, cognitive support and the psychosocial support observed by the receiver as appropriate to work, occupation, business or profession (Brashear, Boles, Bellenger \& Barksdale, 2006).Numerous studies revealed that mentoring has helped employee to inspire the protégé's development in specific areas and to facilitate successful completion of a task (Bozeman \& Feeney, 2007; Glomb \& Welsh, 2005) and sometimes lead to high retention (Parsloe \& Wray, 2000). While these mentoring relationships can produce positive developmental and organizational outcomes, it can sometimes fail due to a variety of causes and problems such as lack of involvement, inadequate experience on the part of the mentor, no leadership involvement, poor planning, unrealistic expectations, and "fuzzy" goals). This study therefore hypothesize that:

Hypothesis 5: Mentoring has positive effect on employees' involvement and performance.

\section{THEORETICAL FRAMEWORK}

Several theories underpin the subject of employee relations. Three (3) theories (class theory, involvement theory and equity theory) were examined.

\subsection{Labour Process / Class Theory}

Labour process or class theory was originally formulated by Karl Marx (translated in 1976). According to Marx, labour process refers to the process whereby labour is materialized or objectified in use values. Labour is here an interaction between the person who works and the natural world such that elements of the latter are consciously altered in a purposive manner. Hence the elements of labour process are; three-fold: first, the work itself, a purposive productive activity; second the object(s) on which that work is performed; and third, the instruments which 
facilitate the process of work. The labour process is sometimes loosely termed "work organization". The theory largely focuses on class struggles between bourgeoisie (employers) and proletariat (employees). This struggle becomes predominant where management of the organizations are trying to maximize profit and reduce cost; on the other hand, employees striving to improve their standard of living and condition of work. The struggle between these classes if not properly controlled and harmonized ultimately leads to workplace conflict. One major aspect of Marx class theory that fully elucidates the subject matter under study is what he termed the pre-alienated worker. He opined that at the point of alienation, the worker is only directed not by self but by organizational forces which he does not have controlled over.

\subsection{Theory of Involvement}

This theory was propounded by Astin (1984). The ideology of Astin centered on the significance of employee involvement. He sees involvement as a strategic means of facilitating almost all the aspects of employees' cognitive and emotional development. He identified three components of employee involvement which includes informative involvement, involvement with management, and involvement with other co-worker. By implication, this theory implies that, the more involved an employee is with the organization, the higher likelihood of employee retention. In order to cope with the changing competitive environment, Roberts, Thomas and Bartram (2012) contended that organizations need to engage people who are capable of being both managers and leaders in the way they influence, mentor and develop others in formal and informal capacities.

\subsection{Adams' Equity Theory}

J. Stacy Adams, a workplace and behavioral psychologist in 1963 adduced that equity theory shows how a person views fairness in regard to social relationships. A person identifies the amount of input gained from a relationship compared to the output, as well as how much effort another person puts forth. Equity Theory suggests that if an individual thinks there is an inequality between two groups or individuals, the person is likely to be distressed because the ratio between the input and the output are not equal which will lessen motivation and lead to decrease job commitment by the party which feels cheated. Employees compare the outcome of their input to that of similar worker performing similar activities. Hence, the work place relationships would be decided by the degree of equity provided by the conditions of work. Workers would discharge their duties more and improve production and feel part of the organization when they perceive there is equality between their inputs and the resultant output. Hence, equity theory has actually examined the relationship between employees work behavior and employment relations. Equity theory explains that employees cognitively make comparison of their inputs (knowledge, skills, abilities, time, energy, qualification, experience, etc) into an organization with that of comparable person or persons (similar in inputs) within and outside the organization. By implications, where employee perceives a wide gap between input and output in terms of pay inequality, such organizations may be a victim of increased insecurity, anxiety, low organizational commitment, high labour turnover, low productivity and involvement (Gallagher \& Sverke, 2005).

\section{MATERIALS AND METHODS}

This study is descriptive in nature using survey research design. The study population from which the sample was drawn comprises of staff and management of a Public (State) university in SouthWest, Nigeria. The population of the state university is 1158.Using Mason (1978) formula, 212 was adopted as the sample size. Therefore, two hundred and twelve questions (212) copies of the questionnaire were administered to both academic and non-academic members of Lagos State University, South west, Nigeria and only one hundred and thirty-six (136) copies of the questionnaire were valid and used for this study, yielding sixty-four (64) percent of the total questionnaire administered.

The structured questionnaire for the survey contained two (2) sections; the first section sought for the demographic characteristics of the respondents while the second section contained fifteen (15) items out of which the employment relation strategy items were adapted from Armstrong (2005). However, the independent variables (organizational policies, equity, career development and mentoring); moderating variables (employee retention, satisfaction and involvement); and dependent variable (performance) were adapted from literature reviewed and each item was based on 5-Likert scales ranging from strongly agree (5) to strongly disagree (1). The procedure result of the reliability statistics test based on standardized items has Cronbach's Alpha of .793, considering the fact that .70 is the acceptable cut-off value.

Responses were analyzed with the use of Statistical Package for Social Sciences (SPSS) AMOS 21, with the adoption of Structural Equation Modelling 
Table 1: Demographic Composition of the Sample (136)

\begin{tabular}{|c|c|c|}
\hline Characteristics & Sub-Profile & Percentage \\
\hline \multirow[t]{2}{*}{ Gender } & Male & 67.9 \\
\hline & Fermale & 32.1 \\
\hline \multirow[t]{4}{*}{ Age } & $20-29$ years & 24.7 \\
\hline & $30-39$ years & 42.6 \\
\hline & $40-49$ years & 22.7 \\
\hline & 50 years and above & 10.0 \\
\hline \multirow[t]{2}{*}{ Marital Status } & Married & 70.2 \\
\hline & Single & 29.8 \\
\hline \multirow[t]{4}{*}{ Educational Qualification } & $\mathrm{BSc} / \mathrm{HND}$ & 18.8 \\
\hline & $\mathrm{MSc} / \mathrm{MBA}$ & 55.4 \\
\hline & $\mathrm{PhD}$ & 22.5 \\
\hline & Others & 3.3 \\
\hline \multirow[t]{3}{*}{ Work Experience } & $0-5$ years & 38.8 \\
\hline & $6-10$ years & 49.3 \\
\hline & $11-15$ years & 11.9 \\
\hline
\end{tabular}

(SEM) to obtain regression and correlation between observed variables and also regression between the dependent and independent constructs of the study. Various fit indices were utilized in assessing the overall fit of the study model.

\subsection{Results and Discussion}

The demographic characteristics of the respondents are depicted in Table 1 . The male gender constituted $67.9 \%$ of the population; age 30 to 39 years old represented $42.6 \%$. In terms of relevance, the age distribution of the respondent could be said to be adequate for this survey. Expectedly, employees ranging from 30 to 39 years tend to be prone to be old enough to handle relationship with the superior. In addition, $65.9 \%$ of the respondents are married. Furthermore, $55.4 \%$ are with MSc/MBA. This shows that the respondents are literate and educated to provide reasonable answers to the questions; while $35.3 \%$ of the respondents have worked with the organization for 6-10 years.

Table 2 displays the model fit summary for the survey. Bentler and Wu (2002); Bentler and Bonett (1980); and Kaplan (2000) argued that different indicators of goodness-of-fit are usually adopted in various research concepts. Further, the higher the number of the indices of indicators, the acceptable of a good fit such as Normed Fit Index (NFI) =>.90; and Comparative Fit Index (CFI) acceptable value $=>.90$. Other informative indices that measure the close association between the model and the data include Root Mean Squared Error of Approximation (RMSEA); Goodness of fit (GFI); etc.

The goodness of fit explains the close association that exists between the observed and expected values. Obtained scores are therefore compared with the cut-off values (Bentler \& Wu, 2002; Bentler \& Bonett, 1980) in order to establish the degree of fit. The fit index shows that NFI = .958; $\mathrm{CFI}=.962 ; \mathrm{GFI}=.987 ; \mathrm{CMIN} / \mathrm{df}=3.303$ and minimum score as indicated in the cut-off values was achieved as shown in Table 2.

Figure 2 depicts standardized estimates of the structural model outlining the path coefficient scores of the observed variables in the study. It is evident in the coefficient scores obtained that close association exists amongst the tested variables (mentoring, recognition, equity, promotion and organizational policies), while the regression

Table 2: The Model Fit Summary

\begin{tabular}{lrr}
\hline \multicolumn{1}{c}{ Model-Fit Index } & Score & Recommended Cut-off Values \\
\hline $\begin{array}{l}\text { Chi-square/Degree of Freedom (CMIN/DF) } \\
\text { Normed Fit Index (NFI) }\end{array}$ & 3.303 & Accepts value limit of less than 5 \\
Comparative Fit Index (CFI) & .958 & $=>.90$ \\
Root Mean Squared Error of Approximation & .962 & $=>.90$ \\
(RMSEA) & .003 & .05 or less $=$ good \\
Goodness of Fit (GFI) & .987 & $=>.90$ \\
\hline
\end{tabular}




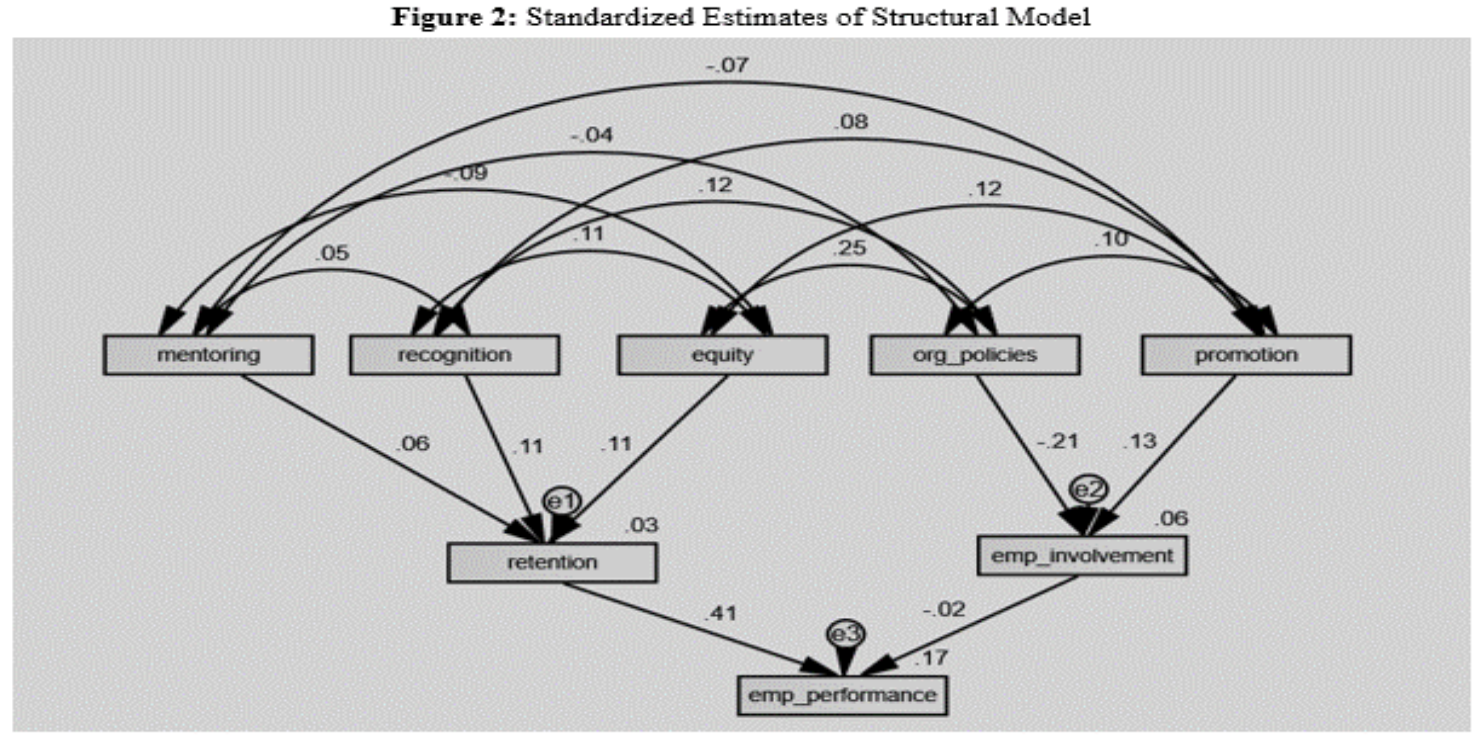

weights are depicted in Table 3. The parameter estimate as depicted in Figure 2 indicates that promotion is the most significant predictors of performance with aid of the mediating variable (retention). When recognition goes up by 1 standard deviation, retention goes up by 0.11 standard deviations. When mentoring goes up by 1 standard deviation, retention goes up by 0.065 standard deviations. When promotion goes up by 1 standard deviation, employee involvement goes up by 0.133 standard deviations. When equity goes up by 1 standard deviation, retention goes up by 0.113 standard deviations. When organizational policies go up by 1 standard deviation, employee involvement goes down by 0.208 standard deviations.

Mentoring (H5), recognition (H2) promotion (H4) and equity (H3) were found to be indirectly and statistically significant of the prediction of performance. Therefore, the study hypothesized statements were accepted. While organizational policies (H1) exerted negative and insignificant influence on performance. As obtained in the literature, organizational policies play a significant role in employees' performance. However, the results obtained from the survey are contrary to the earlier studies in which positive and significant relationship were identified between organizational policies (Demet, 2012; Albrecht, 2010; Dessler, 2004) and performance. By implications, since employees have no control over policies such as sick days, insufficient provision of conference supports and research grants, workplace safety procedures and policies regarding career and capacity development, these may be the factors that could be responsible for low performance.

\section{MANAGERIAL IMPLICATIONS AND CONCLUSION}

The principal objective of the study is to identify the relationship between employee relation strategies and employees' performance using a case organization within the Nigerian educational sector. It is evident that employee relation strategies influence employees' performance. Therefore, the study provides insight to the effect of employee relation strategies taking into consideration variables such as flexible organizational policies,

Table 3: Regression Weights of the Sample

\begin{tabular}{lllccccc}
\hline \multicolumn{1}{c}{$\begin{array}{c}\text { Moderating } \\
\text { Variables }\end{array}$} & & \multicolumn{1}{c}{$\begin{array}{c}\text { Independent } \\
\text { Variables }\end{array}$} & Estimate & S.E. & C.R. & P & Hypotheses \\
\hline Emp_involvement & $\leftarrow$ & Mentoring & .065 & .091 & .760 & .448 & $\mathrm{H}_{5}-$ Accept \\
Emp_involvement & $\leftarrow$ & Promotion & .133 & .033 & 1.579 & .114 & $\mathrm{H}_{4}-$ Accept \\
Retention & $\leftarrow$ & Equity & .113 & .071 & 1.326 & .185 & $\mathrm{H}_{3}-$ Accept \\
Retention & $\leftarrow$ & Recognition & .110 & .079 & 1.288 & .198 & $\mathrm{H}_{2}-$ Accept \\
Retention & $\leftarrow$ & $\begin{array}{l}\text { Organizational } \\
\text { policies }\end{array}$ & -.208 & .083 & -2.470 & .014 & $\mathrm{H}_{1}-$ Reject \\
\hline
\end{tabular}


recognition, equity, promotion and mentoring on employees' performance through mediating variables such as employee involvement and retention. The implication for decision makers is that the more an organization engages in supportive employee relation strategy, the higher the retention level which will ultimately lead to increased job performance. Obviously, managers should pay more attention to the proper management of flexible organizational policies, consistent promotional system and mentoring programmes as these variables have positive and significant effects on employees' performance. Recognition and equitable pay should serve as a competitive advantage in order to increase employees' efficiency. Based on the obtained result from the study, organizational policies have negative and insignificant effect on performance, which suggest that increase in employees' performance will require that managers pay more attention to flexible organizational policies. This might be an isolation case since the study was conducted in an institution within a particular zone, however it is expedient to suggest that future study may wish to explore the effect of organizational policies on employees' performance in other institutions within the Nigerian education sector.

\section{REFERENCES}

Adams, S. (1963). Toward an understanding of inequity. Journal of Abnormal and, Social Psychology, 67(5), 422-436.

Adeniji, A. \& Osibanjo, A. (2012). Human resource management: Theory and practice. Lagos: Pumark Nigeria Limited.

Al-Anzi, N. (2009). Workplace environment and its impact on employee performance. (A Thesis Submitted in partial fulfilment of the Requirements of Open University of Malaysia for the Degree of Master of Business Administration).Open University of Malaysia, Bahrain.

Albrecht, K. (2010). Employer-employee relations. New York: Simon and Schuster, Business and Economics.

Allen, T., Eby, L., \& Lentz, E. (2006). Mentorship behaviors and mentorship quality associated with formal mentoring programs: closing the gap between research and practice. Journal of Applied Psychology, 91(3), 567-578.

Allen, T., Eby, L., Poteet, M., Lentz, E. \& Lima, L. (2004). Career benefits associated with mentoring for protégés: a meta-analysis. Journal of Applied Psychology, 89, 127-36.

Aluko, M.A.O. (2007). Factors that motivate the Nigerian workers. Ife Social Sciences Review, Obafemi Awolowo University, Ile-Ife, Nigeria, 15(1), 190-199.

Armstrong, D. (2005). Organization in the Mind: A managerial action. CIPD: London.

Astin, A. W. (1984). Student involvement: A developmental theory for higher education. Journal of College Student Personnel, 25(4), 297-308.

Banjoko, S. (2002). Human resource management, Lagos: Pumark Nigeria Limited.

Bentler, P. \& Bonett, D. (1980). Significance tests and goodness of fit in the analysis of covariance structures. Psychological Bulletin, 88(3), 588-606.

Bentler, P. M., \& Wu, E. J. C. (2002). EQS 6 for Windows user's guide. Encino: Multivariate Software.

Bozeman, B. \& Feeney, M. (2007). Toward a useful theory of mentoring: A conceptual analysis and critique. Administration \& Society, 39(6), 719-739.

Brashear, T., Boles, J., Bellenger, D. \& Barksdale, H. (2006). An exploratory study of the relative effectiveness of different types of sales force mentors. Journal of Personal Selling and Sales Management, 26(1), 7-18.

Carter, M. R. \& Aston, M. (2002). Team-based working in healthcare: An organisational level perspective. 
Journal of Occupational Health Psychology, 8 (1), 62-70.

Chan, W., \& Mak, C. (2012). The influence of job and career attitudeson learning motivation and transfer. Career Development International, 6 (1). 20-28.

Cooper, L. \& Payne, R. (2008). Causes, Coping and Consequences of retention at Work. New York: Wiley.

Crandall, R. \& Perrewe, L. (2005). Employee relation strategies: A Handbook. New York: Taylor \& Francis.

Demet, L. (2012). Impact of Workplace Quality on Employee's Productivity: A Case Study of a Bank in Turkey. Journal of Business Economics and Finance. $1(1), 38-50$

Dessler, G. (2004). Management: Principle and Practices for Tomorrow's Leaders, 3rd Edition. New Jersey: Person Education, Inc.

Falola, H., Ibidunni, S. \& Olokundun, A. (2014). Incentives packages and employees' attitudes to work: A study of selected government parastatals in Ogun State, South-West, Nigeria. International Journal of Research in Business and Social Science, $3(1), 2147-4478$.

Finegold D. \& Frenkel S. J, (2006). Managing people where people really matter: The management of human resources in biotech companies. International Journal of Human Resource Management, 17, 1 - 24.

Gallagher, D.G. \& Sverke, M. (2005). Contingent employment contracts: Are existing theories still relevant? Economic and Industrial Democracy, 26, 181-203.

Gennard, J. \& Judge, G. (2002). Employer-employee relations. London: CIPD.

Glomb, T. \& Welsh, E. (2005). Can opposites attract? Personality heterogeneity in supervisor-subordinate dyads as a predictor of subordinate outcomes. Journal of Applied Psychology, 90(4), 749-757.

Greenberg, S. \& Baron, D. (2003). Training and turnover in the evolution of organizations. Organization Science, 8(1), 84-96.

Hameed, A. (2009). Impact of office design on Employees' productivity: a case study of banking organizations of Abbottabad, Abbottabad, Journal of Public affairs, Administration and Management, 3(1), 1-5.

Harlow, E. \& Lawler, J. (2000). Management, Social Work and Change. Aldershot: Ashgate.

Hicks, T. \& Caroline, M. (2007). A guide to managing workplace stress. California: Universal Publishers.
Huges, J. (2007, July 2). Office design is pivotal to employee productivity. Sandiego Daily Transcript.

Kaplan, D. (2000). Structural equation modeling: Foundations and extensions. Thousand Oaks: Sage Publications.

Kaufman, T., Chapman, T. \& Allen, J. (2013). The effect of performance recognition on employee engagement. New York: Cicero Group.

Leblebici, D. (2012): Impact of workplace quality on employee's productivity: Case study of a bank in Turkey, Journal of Business, Economics and Finance, l(1), 38-40.

Manjunath, V. \& Rajesh, C. (2012).Competency based compensation system - as a strategic human resource technique. International Journal of Manpower, 38(7), 780-810.

Mason, P (1978). Stress and coping: An anthology. Columbia: Columbia University Press.

Mike, L. (2008). Employer-employee relations, Edinburgh Business School. Edinburgh: Heriot-Watt University.

Nelson, A. \& Quick, G. (2005). The effects of contingent and non-contingent rewards and controls on intrinsic motivation. Organizational Behavior and Human Performance, 8(2), 217-229.

Nelson, B. (2005). 1001 ways to reward your employees, (2nd edition), New York: Workman Publishing Company.

Nolan, S. (2012).A look of current trends data, Strategic HR Review, 11(3), 32-54.

Oakland, S. \& Oakland, J. (2001). Current people management activities in world class organisations. Total Quality Management, 12(6), 773-788.

Osibanjo, A., Salau, O. \& Falola, H. (2014). Modeling the relationship between motivating factors; Employee retention; and job satisfaction in the Nigerian banking industry. Journal of Management Policies and Practices. 2(2). 63-83.

Parsloe, C. (2000). Work motivation in organizational behavior. New York: Psychology Press.

Parsloe, E. \& Wray, M. (2000). Coaching and mentoring: practical methods to improve learning. Kogan Page.

Pinder, C. (2008). Work motivation in organizational behavior. New York: Psychology Press.

Pompper, D. \& Adams, J. (2006). Under the microscope: Gender and mentor-protege relationships. Public Relations Review, 17 (32), 309-315.

Redmond, B. (2013). Lesson 5: Equity theory: Is what I get for my work fair compared to others? Work 
attitudes and motivation. The Pennsylvania State University World Campus.

Robbins, S. \& Judge, A. (2008). Organizational behavior (13th edition). Prentice Hall.

Roberts, O., Thomas, A. \& Bartram, S. (2012). Job motivation in organizational behavior. New York: Psychology Press.

Rothwell, W. J. \& Kazanas H. C. (2004). The strategic development of talent. Human Resource Development Press, Massachusetts.

Siegel, P., Schraeder, M. \& Morrison, R. (2007). A taxonomy of equity factors. Journal of Applied Social Psychology, 38(1), 61-75.

Spector, P.E. (2008). Industrial and organizational behavior (5th edition). Wiley: Hoboken, NJ.

Stajkovic, A. \& Fred, L. (2003). Behavioral management and task performance in organizations: conceptual background, meta-analysis, and test of alternative models. Personnel Psychology, 56(1), 155-194.

Stecher, M.D. \& Rosse, J.G. (2007). Understanding reactions to workplace injustice through process theories of motivation: a teaching module and simulation. Journal of Management Education, 31(2), 777-796.

Taiwo, A. (2010). The influence of work environment on employee performance: a case of selected oil and gas industry in Lagos, Nigeria. African Journal of Business Management, 4(3), 299-307.

Wagner, R. \& Harter, J. (2006) The elements of great managing, New York: Gallup Press. 